\title{
REPRESENTASI CYBER SOCIETY DALAM FILM “SEARCHING”
}

\author{
Rikha Ayu Minda Kharisma dan Rahmawati Zulfiningrum \\ Universitas Dian Nuswantoro \\ rikhaayuu@gmail.com, rahmawati.zulfiningrum@dsn.dinus.ac.id
}

\begin{abstract}
Abstrak
Masyarakat cyber merupakan salah satu bentuk penciptaan budaya baru yang disebabkan oleh perkembangan teknologi informasi dan komunikasi. Teknologi saat ini memiliki banyak manfaat untuk membantu masyarakat dalam menyelesaikan aktivitas rutinnya, dimana digitalisasi telah terjadi di berbagai bidang dan menjadi kebiasaan baru masyarakat. Searching, salah satu film yang diproduksi tahun 2018 ini mengisahkan fenomena teknologi. Film tersebut menggambarkan bahwa menemukan orang hilang dengan rekam jejak digital adalah mungkin dan bisa menjadi jalan keluarnya. Lebih jauh, film ini tidak hanya menampilkan dampak positif dari teknologi tetapi juga menyuguhkan sisi negatifnya. Penelitian ini bertujuan untuk mengetahui representasi masyarakat cyber dalam film Searching. Peneliti menggunakan metode penelitian deskriptif kualitatif dengan model analisis semiotika Roland Barthes. Teori dalam penelitian ini menggunakan Teori Representasi Stuart Hall. Hasil penelitian menunjukkan bahwa terdapat lima representasi dari masyarakat cyber. Pertama, komunikasi yang menggunakan media aplikasi. Kedua, menciptakan identitas baru di dunia maya. Ketiga, menggunakan website untuk mencari informasi. Keempat, kebebasan berpendapat di dunia maya, dan yang terakhir adalah kecanduan internet. Masyarakat perlu meningkatkan kesadaran akan dampak penggunaan teknologi agar bisa hidup bijak di era digital.
\end{abstract}

Kata kunci: Film searching, M asyarakat cyber, Representasi, Semiotika, Teknologi

\begin{abstract}
The cyber society is a form of creating a new culture caused by the development of information and communication technology. Nowadays, technology bring the advantages to help people accomplished their routine activities, where digitalization has occurred in various fields and has become a new habit for society. Searching, one of the movies that produce in 2018 is portray the phenomenon of technology. The film described that finding the missing people with a digital track record is possible and could be the way out. Furthermore, this film not only show the positive impact of technology but also state the negative side. This study aims to determine the representations of cyber society in film title Searching. The researcher uses qualitative descriptive method research with semiotics of Roland Barthes analysis model. The theory in this study uses the theory representation of Stuart Hall. The results showed that there are five
\end{abstract}


representations of cyber society. First, communication using media applications. second, creating a new identity in cyberspace. Third, use the website to find information. Fourth, freedom of speech in cyberspace, and the last is internet addiction. The public needs to increase the awareness for the impacts of technology uses in order to live wisely in the digital era.

Keywords Cyber society, Representation, Searching movie, Semiotic, Technology

\section{Pendahuluan}

Masyarakat cyber (cyber society) merupakan istilah dari pesatnya perkembangan teknologi komunikasi di bidang informasi, salah satunya adalah internet. Masyarakat terbagi menjadi dua kategori, yaitu masyarakat dunia nyata dan masyarakat dunia maya (Bungin, 2007:160). Cyber society dibangun berdasarkan interaksi sosial dan proses sosial kehidupan kelompok atau jaringan sesama masyarakat maya. Interaksi atau proses tersebut bisa bersifat sementara atau dalam waktu yang lama tergantung dari kepentingan masyarakat tersebut. Pada interaksi sosial sementara, anggota hanya sepintas ingin berjalan-jalan di dunia maya melalui browsing atau searching. Biasanya dilakukan untuk keperluan mencari informasi atau mengerjakan tugas. Interaksi sosial yang berlangsung cukup lama antar anggota masyarakat maya biasanya disebut dengan netter. Pengguna tersebut setiap saat berada dalam dunia maya untuk bergaul, berbisnis, belajar bahkan hingga melakukan tindak kejahatan maya yang biasa disebut dengan cybercrime (Nugraha, 2014:683).

Digitalisasi merupakan proses konversi berbagai informasi maupun berita dari format analog menjadi format digital agar lebih mudah untuk di akses. Informasi digital biasanya disajikan dalam bentuk gambar, teks, audio, ataupun video (Deegan, 2002:38). Teknologi informasi dan digital dalam segala bidang telah diadopsi oleh Indonesia, bahkan mengalami perkembangan yang pesat. Dikutip dari laman Kompas (Widiarini, 2020), digitalisasi perbankan menjadi salah satu kebutuhan dalam menghadapi tantangan di era digital. Menurut Jahja Setiaatmaja selaku Presiden Direktur PT Bank Central Asia Tbk, digitalisasi dapat menciptakan efisiensi bagi bank dan juga nasabah. Adopsi e-commerce juga 
sebagai bentuk digitalisasi di Indonesia. Menurut hasil riset Merchant Machine pada 2018, Indonesia merupakan negara dengan pertumbuhan e-commerce tercepat mencapai 78 persen. Digitalisasi transportasi juga mengubah pola mobilitas di Indonesia. Kini pengguna transportasi umum dapat memantau informasi jadwal keberangkatan hingga memesan tiket secara digital melalui aplikasi maupun website khusus.

M enurut data dari laman We are Social (Kemp, 2020) pada Januari 2020 jumlah pengguna Internet di Indonesia sebanyak 175,4 juta dengan total populasi penduduk berjumlah 272,1 juta jiwa. Manusia hidup berdampingan dan tak bisa dipisahkan dari internet. M enurut hasil riset digital yang dilakukan We are social (Kemp, 2020), media sosial menjadi media teknologi informasi yang paling digemari masyarakat. Pada sekian banyak kelebihan internet, manusia seringkali melupakan bahwa ada pula dampak negatif yang mengancam. Penyalahgunaan internet dapat memicu hal-hal negatif hingga mengarah kepada tindak kriminal.

Dewasa ini banyak film maker yang menciptakan film bertema teknologi internet. Film yang menggunakan media sosial sebagai benang merahnya adalah film "Searching". "Searching" merupakan sebuah film yang yang menampilkan tentang kecanggihan teknologi. Sepanjang film disuguhkan adegan visual yang berhasil membuat takjub mata penonton. Film yang di rilis pada 24 Agustus 2018 ini disutradarai oleh Aneesh Chaganty. Berhasil meraih penghargaan Festival Film Sundance 2018, kategori Audience Award Next yaitu Alfred P. Sloan Feature Film Prize (Pedersen, 2018). Film berdurasi 102 menit ini menceritakan tentang David Kim, seorang ayah yang melakukan pencarian terhadap putrinya yang hilang di San Jose, California. Pencarian dimulai dari jejak digital M argot. David Kim mencoba menelusuri akun pribadi sang anak, dengan bantuan seorang detektif, yaitu Rosemary Vick (IM Db, 2018).

Film ini menampilkan adegan-adegan penggunaan berbagai jenis teknologi terutama penggunaan media komunikasi. Sepanjang alur cerita, 
diperlihatkan sang tokoh menggunakan laptop dan handphone untuk berkomunikasi secara online. Di akhir film ditunjukan bahwa ternyata teknologi internet memiliki dampak negatif yang membahayakan yaitu tokoh Margot yang hilang akibat penipuan yang dilakukan oleh teman media sosialnya. Kelebihan yang dimiliki oleh film "Searching" adalah kontekstualisasinya ke dalam era digital. Dalam proses pencarian tersebut, penonton diajak untuk turut melihat layar laptop dan handphone dengan mata penonton. Memanfaatkan perkembangan teknologi untuk membalut unsur thriller investigasi membuat "Searching" lebih dari sekedar film pencarian anak hilang. Penonton dikejutkan oleh alur yang merepresentasikan dampak media sosial yang bahkan diluar benak manusia. Berdasarkan uraian latar belakang tersebut, penelitian menjadi penting karena akan melihat bagaimana representasi cyber society dalam film "Searching".

\section{Tujuan Penelitian}

Tujuan dari penelitian ini adalah untuk mengetahui representasi cyber society dalam film "Searching".

\section{Kerangka Teori}

\subsection{Teori Representasi Stuart Hall}

Teori ini mengungkapkan bahwa representasi merupakan penggunaan bahasa (language) untuk menyampaikan sesuatu yang berarti (meaningful) kepada orang lain. Representasi menjadi bagian terpenting dari proses dimana arti (meaning) diciptakan dan dibagi kepada anggota kelompok dalam sebuah kebudayaan (culture). Menghubungkan antara konsep (concept) dalam benak individu dengan menggunakan bahasa yang memungkinkan seseorang untuk mengartikan orang, benda, kejadian yang nyata (real), dan dunia imajinasi dari orang, benda, obyek, serta kejadian yang tidak nyata (fictional). Teori representasi dapat diklasifikasikan menjadi tiga bentuk pendekatan, yaitu 
reflective approach, intentional approach, dan constructionist approach (Hall, 2002:13).

a. Pendekatan reflektif (reflectif approach) artinya bahasa sebagai cermin yang merefleksikan makna yang sebenarnya. Sebuah makna tergantung pada obyek, orang, ide atau peristiwa yang ada pada dunia nyata. Bahasa berfungsi sebagai cermin yang konsepnya memantulkan arti sebenarnya seperti yang ada di dunia.

b. Pendekatan intensional (intentional approach) berarti menggunakan bahasa untuk berkomunikasi sesuai dengan pandangan penciptanya. Pada pendekatan ini, pembicara atau penulis mengungkapkan pengertiannya yang unik kedalam dunia melalui bahasa. Salah satu cara mengetahui makna, sebaiknya menanyakan kepada pembuat subyek agar tidak keliru dalam memaknai.

c. Pendekatan konstruksi (constructionist approach) berarti mengkonstruksi makna lewat bahasa yang digunakan. Pendekatan ini berfungsi untuk mengenali publik dan karakter sosial dari bahasa. Termasuk kode-kode visual seperti suara, gambar, dan tanda. Pada pendekatan konstruktivis siapapun bisa menemukan dan memaknai suatu hal tersebut berdasarkan apa yang dimengerti oleh seseorang (Hall, 2002:24).

\subsection{Semiotika Roland Barthes}

Semiotika berasal dari kata Yunani "semeion" dan dari bahasa Inggris yaitu "semiotic" yang artinya tanda. Teori semiotika merupakan ilmu yang mempelajari mengenai tanda (sign), fungsi tanda, dan juga produksi makna. Tanda diartikan sebagai suatu dasar konvensi sosial yang terbangun sebelumnya dapat dianggap memiliki arti lain. Semiotika diartikan sebagai ilmu yang mempelajari sederetan luas obyek, peristiwa dan kebudayaan sebagai tanda. Menurut Littlejohn dalam Theorist on Human Behaviour, manusia dengan 
perantaraan tanda-tanda dapat melakukan komunikasi dengan manusia lain (Wibowo, 2013:7).

Roland Barthes mengungkapkan kunci dari analisisnya adalah konsep tentang two order of signification berupa konotasi dan denotasi. M endefinisikan tanda (sign) sebagai sebuah sistem yang terdiri dari ekspresi (signifier) dalam hubungannya dengan konten (signified). Tahap pertama yaitu hubungan antara signifier dengan signified dalam tanda realitas eksternal. Tahap pertama disebut sebagai denotasi yang berarti makna paling nyata diantara tanda-tanda. Tahap kedua merupakan interaksi yang terjadi akibat tanda bertemu dengan kenyataan atau emosi dan juga dari nilai-nilai budaya, tahap tersebut disebut dengan konotasi (Sobur, 2009:69).

\subsection{Film}

Film merupakan sebuah media massa yang dikemas dalam format hiburan. Film juga mengandung nilai informatif, edukatif dan persuasif. Seiring perkembangan zaman, saat ini film sangat berdampingan dengan masyarakat. Bahkan bisa mempengaruhi penonton, baik secara pola pikir, perilaku maupun sikap (Effendy, 2003:212). Film didefinisikan sebagai hasil budaya dan alat ekspresi kesenian. Film adalah gabungan dari berbagai teknologi seperti fotografi dan rekaman suara. Seni rupa, seni teater, bahkan seni arsitektur juga turut berperan dalam sebuah film (Effendy, 2003:239). Pada teknik perfilman, baik peralatannya maupun pengaturannya telah berhasil menampilkan adegan yang sangat mendekati kenyataan. Pada suasana gelap dalam bioskop, penonton menyaksikan suatu cerita yang seolah-olah benar-benar terjadi dihadapannya (Effendy, 2003:207). Tumbuh dan berkembangnya film sangat bergantung pada teknologi dan paduan unsur seni sehingga menghasilkan film yang berkualitas (McQuail, 2003:110). 


\subsection{Cyber Society}

Cyber society atau masyarakat cyber adalah kondisi masyarakat yang tercipta sebagai konsekuensi dari perkembangan teknologi informasi dan komunikasi, khususnya internet. Cyber society tidak dibatasi oleh wilayah dan ruang. Orang yang berada di berbagai daerah dapat berkomunikasi secara aktif melalui media sosial. Cyber society merupakan sebuah kehidupan masyarakat yang tidak dapat secara langsung di indera melalui panca indera manusia, tetapi dapat dirasakan dan disaksikan sebagai sebuah realitas sebagai akibat perkembangan teknologi informasi dan komunikasi (Nugraha, 2014:683). Internet telah membuat sebagian besar masyarakat menjadi bergantung pada fasilitas-fasilitasnya. Teknologi media telah menciptakan revolusi di tengah masyarakat karena sangat ketergantungan dengan teknologi. Tatanan masyarakat terbentuk berdasarkan pada kemampuan masyarakat menggunakan teknologi. Media menjadi sangat berperan dalam menciptakan dan mengelola budaya (M cLuhan, 2003:125).

\section{Metode Penelitian}

Penelitian terdahulu yang relevan dan digunakan sebagai state of the art diantaranya adalah pertama, Representasi Perempuan Metropolitan dalam Film 7 Hati 7 Cinta 7 Wanita oleh Sigit Surahman (2014). Hasil kesimpulan dalam penelitian adalah representasi kaum perempuan di dunia metropolitan yang merasa selalu menjadi korban. Kesamaan dalam penelitian adalah menggunakan teori Representasi dan Semiotika Roland Barthes. Perbedaan dalam penelitian, peneliti merepresentasikan cyber society dalam film "Searching". Kedua, Representasi Feminisme dalam Film "Snow White and the Huntsman" oleh Yolanda Hana Chornelia (2013). Film Snow White and The Huntsman mengandung feminisme dalam pengambilan keputusan, feminisme dalam kekuatan, feminisme dalam kepemimpinan, dan androgini. Persamaan dalam penelitian yaitu menggunakan Teori Representasi. Perbedaan dalam penelitian tersebut adalah menggunakan Teori Television codes John Fiske. Ketiga, Analisis 
Semiotika Makna Islam dalam Film Pengabdi Setan yang diteliti oleh Dimas Lazuardy Abdullah. Hasil penelitian ditemukan makna Islam, diantaranya akidah, yakni dengan mempercayai keberadaan Jin atau syaitan. Syariat, yakni dengan kewajiban melaksanakan ibadah shalat sebagai bentuk perlindungan dari perbuatan keji dan mungkar. Serta akhlak Islam melalui sikap sabar dalam menghadapi musibah. Sedangkan perbedaan dalam penelitian, peneliti merepresentasikan cyber society dalam film "Searching".

Penelitian ini menggunakan metode kualitatif dengan teori representasi dan analisis Semiotika Roland Barthes. Data primer diperoleh dari observasi terhadap tayangan film "Searching", sedangkan data sekunder diperoleh dari sumber literatur buku, jurnal dan berita online. Objek penelitian ini adalah representasi cyber society yang kemudian dianalisis melalui adegan, dialog dan tokoh untuk mengetahui gambaran cyber society dalam film "Searching". Teknik analisis data yang digunakan dalam penelitian ini adalah semiotika Roland Barthes. Semiotika Roland Barthes dibagi menjadi dua sistem yang biasa disebut "two order of signification". Sistem analisis pertama yaitu denotasi dan sistem analisis kedua adalah konotasi. Selain dua kajian utama tersebut, Roland Bartes juga menyertakan aspek mitos. Model semiotika Roland Barthes seperti tersaji pada Gambar 1.

\begin{tabular}{|l|l|l|}
\hline $\begin{array}{l}\text { 1. } \\
\begin{array}{l}\text { Signifier } \\
\text { (Penanda) }\end{array}\end{array}$ & $\begin{array}{l}\text { 2. Signified } \\
\text { (Petanda) }\end{array}$ \\
\hline 3. Denotatife sign (tanda denotatif) & \\
\hline $\begin{array}{l}\text { 4. Connotative Signifier (penanda } \\
\text { konotatif) }\end{array}$ & $\begin{array}{l}\text { 5. Connotativ signified } \\
\text { (penanda konotatif) }\end{array}$ \\
\hline 6. Connotative sign (tanda konotatif) \\
\hline
\end{tabular}

Gambar 1. Semiotika Roland Barthes

Sumber: (Wibowo, 2013:21) 


\section{Hasil Penelitian dan Pembahasan}

Penelitian ini melakukan tahapan analisis melalui adegan-adegan dalam film untuk mengetahui representasi cyber society dalam film "Searching". Peneliti menggunakan analisa Semiotika Roland Barthes yang terdiri dari tiga tahapan yaitu denotasi, konotasi, dan mitos. Penemuan simbol, makna dan pesan yang merepresentasikan cyber society dalam film "Searching" dilakukan dengan mengobservasi setiap scene, dialog, suasana, dan karakter tokoh. Berikut merupakan hasil analisis data berdasarkan scene dalam film:

\section{a. Komunikasi menggunakan media aplikasi}

Komunikasi merupakan proses sosial yang dilakukan setiap manusia. Komunikasi adalah proses penyampaian pesan yang dilakukan seseorang kepada orang lain, dengan tujuan untuk memberitahukan, mengubah sikap, pendapat atau prilaku orang tersebut. Penyampaian pesan dapat dilakukan secara langsung (lisan) atau tidak langsung (melalui media) (Effendy, 2003:254). Di era digital, berbagai media teknologi diciptakan termasuk aplikasi maupun website. Manusia memiliki budaya atau gaya hidup baru yang tak lepas dari penggunaan teknologi terutama dalam berkomunikasi. Teknologi memiliki fitur yang bisa mereplika komunikasi sehingga seolah-olah menjadi bertemu secara langsung (face to face) yaitu dengan adanya aplikasi panggilan video (video call). Seperti yang tergambar pada scene 2 dalam film "Searching".

Tabel 1 berikut menampilkan adegan David menelpon Margot melalui Face time (video call), hal ini dikarenakan David dan Margot disibukkan dengan aktivitas masing-masing sehingga mereka jarang berkomunikasi secara langsung, dan lebih sering menggunakan media video call untuk berkomunikasi. 
Tabel 1 Scene 2 film "Searching"

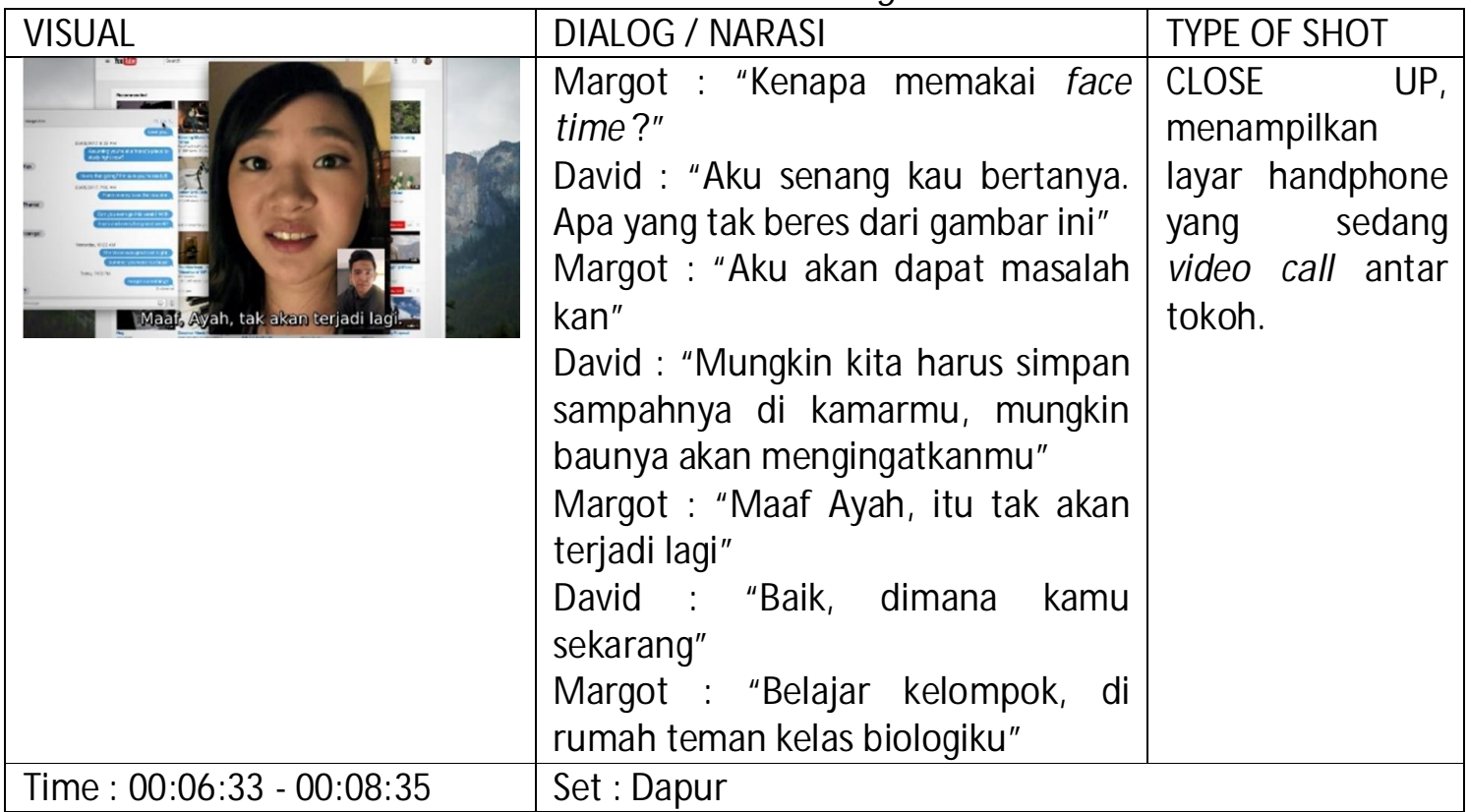

1. Denotasi

Signifier: Visualisasi dan dialog scene 2

Signified: Berkomunikasi jarak jauh dengan aplikasi video call.

Potongan gambar scene 2 diatas memperlihatkan ketika David menelpon

anaknya melalui video call pada pagi hari saat hendak berangkat kerja.

David sudah memakai pakaian rapi dan berada di dapur rumahnya sendirian. Sedangkan Margot terlihat sedang berada dirumah temannya. la menegur Margot karena belum membuang sampah yang ada di dapur.

2. Konotasi

Di pagi hari saat David bersiap berangkat kerja, ia menelepon Margot karena belum membuang tempat sampah yang ada di dapur. Dikarenakan kesibukan masing-masing, David dan M argot jarang berkomunikasi secara langsung. Ketika David bangun di pagi hari dan hendak bersiap kerja, Margot sudah tidak ada di rumah. Setelah pembicaraan singkat tentang tempat sampah selesai, David menanyakan keberadaan anaknya tersebut. Margot menjawab bahwa ia sedang belajar kelompok untuk kelas Biologi 
dan akan pulang sampai larut malam. Saat David ingin berbicara lagi, Margot segera menutup teleponnya. David tampak tidak senang ketika Margot menutup teleponnya secara tiba-tiba karena ia ingin lebih banyak bicara kepada anaknya.

3. Mitos : Tidak terdapat mitos

\section{b. Menciptakan identitas baru di dunia maya.}

Media Sosial adalah media perantara di internet yang membuat penggunanya mempresentasikan dirinya maupun berinterakasi, bekerjasama, saling berbagi, berkomunikasi dengan pengguna lainnya, dan membentuk ikatan sosial secara virtual (Nasrullah, 2016:13). Saat ini masyarakat memiliki akun media sosial yang dapat digunakan secara bebas untuk berkomunikasi dan mengekspresikan diri sehingga terbentuklah identitas diri di dunia maya yang berbeda dari kehidupannya sehari-hari. Seperti yang digambarkan pada scene ke 6 .

Menampilkan adegan David mencari kontak teman sekelompok Margot dalam kelas Biologi yaitu Abigail Nielsen dan menghubunginya melalui video call. Sebelum melakukan panggilan, David stalking akun facebook Abigail terlebih dahulu. Terdapat beberapa foto $M$ argot yang diunggah Abigail dan menandakan keduanya merupakan teman dekat. Namun ternyata Abigail hanya memanfaatkan kepintaran M argot.

Tabel 2 Scene 6 film "Searching"

\begin{tabular}{|l|l|l|}
\hline VISUAL & DIALOG / NARASI & TYPE OF SHOT \\
\hline David : "Kau mengadakan kelompok & MEDIUM \\
bahasa inggris kamis malam untuk & CLOSE UP layar \\
biologi? Jadi kau bersama margot & komputer, \\
pada sebagian besar malam itu?" & menampilkan \\
Abigail : "Kelompok belajarnya & tokoh Abigail \\
hanya sampai jam 9 malam" & dan David \\
David: "Tidak, dia bilang sepanjang & $\begin{array}{l}\text { sedang video } \\
\text { call } \\
\text { malam" } \\
\text { Abigail : "Tidak, sudah jelas dia pergi } \\
\text { jam 9 malam. Mungkin lebih awal" }\end{array}$ \\
\hline
\end{tabular}




\begin{tabular}{|l|l|}
\hline & $\begin{array}{l}\text { David : "Dia bilang ke mana } \\
\text { perginya?" } \\
\text { Abigail : "Tidak juga" } \\
\text { David : "Bagaimana tampangnya apa } \\
\text { dia khawatir? Apa dia ketakutan? } \\
\text { Apa yang dikatakannya?" } \\
\text { Abigail : "Jujur, aku tidak tahu. Kami } \\
\text { tidak begitu dekat" } \\
\text { David : "Mengapa kau mengundang } \\
\text { nya ke kelompok belajar" } \\
\text { Abigail : "Aku berusaha masuk } \\
\text { Berkeley tahun depan" }\end{array}$ \\
\hline Time : 00:32:07 - 00:32:55 & Set : Kamar Margot \& Kamar Abigail \\
\hline
\end{tabular}

1. Denotasi

Signifier: Visualisasi dan dialog scene 6

Signified: Mencari identitas seseorang melalui media sosial.

Pada gambar pertama memperlihatkan David stalking akun facebook Abigail Nielsen yang merupakan teman sekelompok Margot dalam pelajaran Biologi. Abigail pernah mengunggah fotonya bersama $\mathrm{Margot}$ di akun facebooknya dengan caption "My favorite (aka smarter) partner bio ever". David melakukan video call dengan Abigail dan menanyakannya tentang bagaimana kondisi Margot terakhir kali, seperti yang terlihat di gambar kedua.

\section{Konotasi}

Setelah melihat-lihat akun facebook Abigail Nielsen, David menghubunginya melalui video call. David bertanya kepada Abigail karena sebelum Margot menghilang ia sedang belajar kelompok bersamanya. Ketika menanyainya dengan serius, Abigail selalu menjawab seperlunya saja. la terkesan cuek dan tidak perduli. David mengira keduanya merupakan teman dekat karena sekelompok. David sudah tidak bisa menahan amarahnya lagi, ia membentak sambil bertanya mengapa Abigail mengajak Margot untuk sekelompok di pelajaran Biologi jika mereka tidak 
dekat. Ternyata alasan sesungguhnya adalah karena Abigail ingin masuk ke Universitas Berkeley, oleh karena itu ia berniat memanfaatkan kepintaran Margot selama di sekolah.

\section{Mitos}

Dunia maya menciptakan dunia baru bagi setiap individu. Tak jarang hal-hal yang ada di dunia maya berbanding terbalik dengan realitas kehidupan sehari-hari. Sebagai contoh ketika seorang wanita mengunggah foto dirinya di media sosial dengan pakaian yang terlihat mewah, dengan bergaya kekinian, ditambah dengan editan foto agar terlihat lebih aesthetic. Orang yang melihat akun media sosialnya akan beranggapan bahwa orang tersebut adalah orang yang kekinian atau up to date. Padahal dalam kehidupan sehari-harinya, orang tersebut termasuk wanita yang tidak rapi, jarang mandi, dan jarang berdandan.

\section{c. Menggunakan website untuk mencari informasi.}

Era digitalisasi telah membuat kehidupan masyarakat menjadi bergantung terhadap teknologi. Terdapat berbagai software, aplikasi dan juga website yang diciptakan untuk membantu kehidupan masyarakat. Menurut Strauss (2012:17) internet merupakan jaringan global yang terdiri dari berbagai jaringan yang saling berhubungan. Jutaan jaringan ini meliputi individu, organisasi, hingga pemerintahan. Internet menyimpan seluruh informasi dari penjuru dunia, baik dari sektor pendidikan hingga sosial budaya. Di internet pun tersedia laman koran online yang merupakan bentuk digitalisasi dari koran kertas. Seperti yang digambarkan pada scene 16.

Memperlihatkan adegan David menelepon ke kantor Detektif Rosemary Vick sambil kembali mencari informasi tentang Detektif Vick di internet. Ditemukan sebuah laman yang memuat tentang berita program Detektif Vick membangun klinik rehabilitasi bersama mantan narapidana. Ternyata Randy 
Cartoff, orang yang mengaku telah membunuh Margot merupakan mantan narapidana Detektif Vick.

Tabel 3 Scene 16 film "Searching"

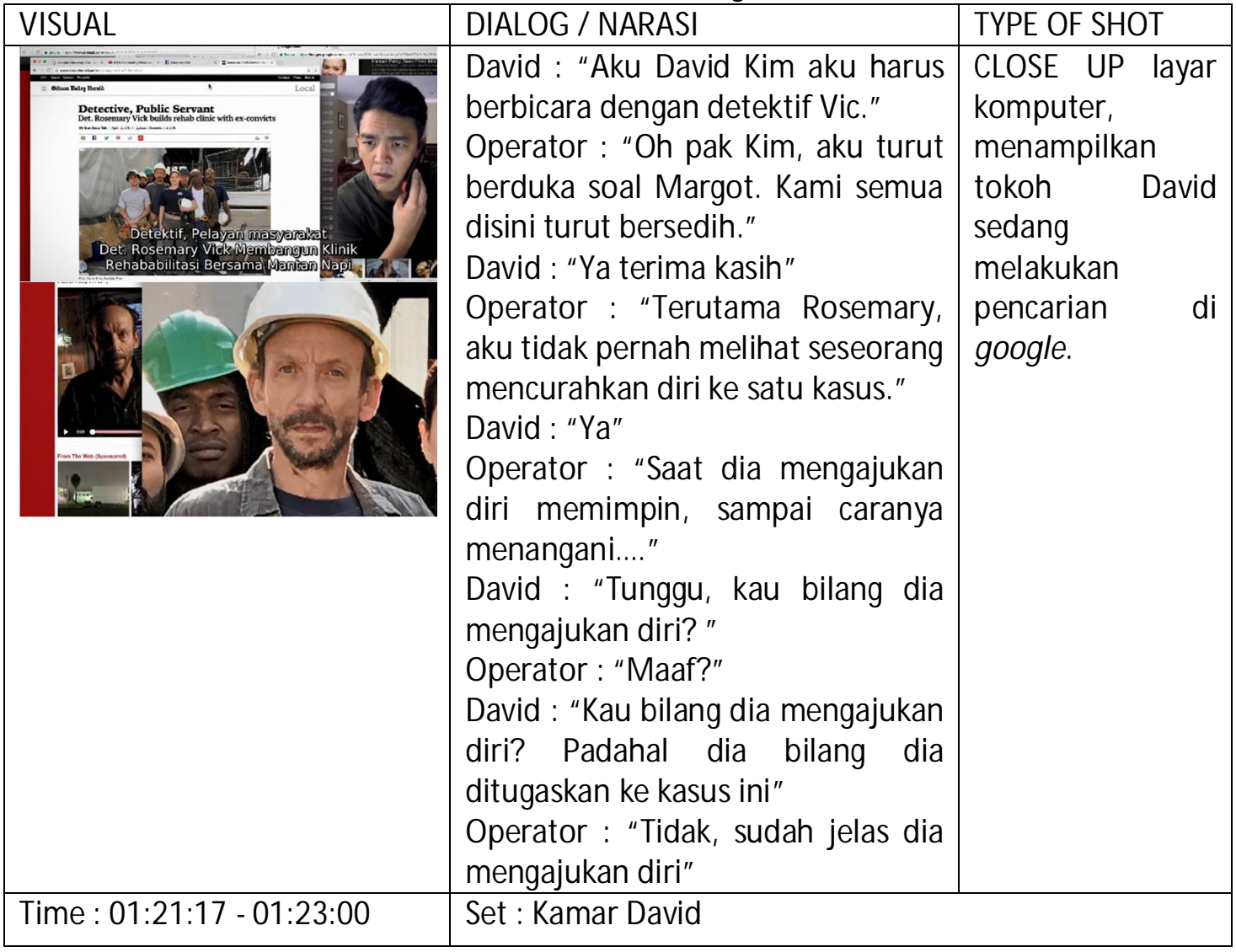

1. Denotasi

Signifier: Visualisasi dan dialog scene 16

Signified: Berita yang tayang di media mudah dipercaya oleh masyarakat.

Pada gambar pertama memperlihatkan David sedang menelepon kantor Detektif Rosemary Vick sambil menjelajahi internet untuk kembali mencari informasi tentang Detektif Vick. Pada gambar kedua terlihat foto Rendy Cartoff bersama dengan Detektif Vick dan juga beberapa orang lainnya dalam artikel berjudul Detektif Rosemary Vick membangun klinik rehabilitasi bersama mantan narapidana seperti yang terlihat pada gambar kedua. 
2. Konotasi

Berkali-kali David menelepon Detektif Vick namun tidak kunjung diangkat. David kemudian menelepon kantor Detektif. David semakin curiga setelah seorang staff yang mengangkat telepon berkata bahwa Detektif Vick dengan sukarela mengajukan diri untuk menangani kasus hilangnya Margot, padahal Detektif Vick mengaku ia ditugaskan oleh kantor. David kembali mengetikkan nama Detektif Vick di kolom pencarian Google. la membaca sebuah artikel tentang pembangunan klinik rehabilitasi bersama mantan napi yang dilakukan oleh Detektif Vick. Dalam artikel tersebut terdapat foto Rendy Cartoff bersama Detektif Vick dan mantan narapidana lainnya. Hal tersebut membuat David semakin curiga. la mencocokan video pengakuan pembunuh dengan foto pada artikel tersebut dan hasilnya sangat mirip.

\section{Mitos}

Rekam jejak digital akan tersimpan dalam jangka waktu yang panjang. Dikutip dari laman CNN Indonesia, menurut pengamat teknologi informatika, Vaksinkom Alfons Tanujaya mengatakan bahwa jejak digital seseorang akan terus bertambah jika aktif menggunakan internet. Jika jejak sudah tercatat di internet maka akan tersimpan selamanya. Rekam jejak digital bagaikan pisau bermata dua yang memiliki dampak positif dan juga negatif. Jejak digital bisa memberikan dampak positif yaitu dapat menyimpan catatan aktivitas yang mendetail dan bertahan lama namun memiliki pengaruh negatif karena bisa diambil dan diedit oleh orang lain sehingga bebas dimanipulasi oleh pengguna internet lain.

\section{d. Kebebasan berpendapat di dunia maya.}

Berita yang hangat diperbincangkan di internet atau media sosial disebut dengan berita viral. Berita viral selalu berhasil menyita perhatian khalayak. Kebebasan berpendapat di internet terutama di media sosial memicu 
berbagai dampak, baik positif maupun negatif. Manfaatnya adalah menimbulkan sifat simpati hingga empati oleh masyarakat. Kebebasan berpendapat juga menimbulkan dampak negatif seperti asumsi masyarakat yang berlebihan hingga memicu penyebaran berita bohong (hoax) dan juga cyberbullying. Seperti yang digambarkan pada scene 13 tentang berita hilangnya M argot yang menjadi viral.

Menampilkan adegan masyarakat luas yang mulai bersimpati dengan Margot melalui media sosial. Tagar \#FindMargot menjadi viral kemudian muncul spekulasi masyarakat tentang Parent Fail atau kegagalan David sebagai Ayah dalam merawat Margot. Komentar masyarakat mulai memojokkan David hingga muncul gambar meme foto David yang telah di edit. David menjadi korban cyber bullying.

Tabel 4 Scene 13 film "Searching"

\begin{tabular}{|c|c|c|}
\hline VISUAL & DIALOG / NARASI & TYPE OF SHOT \\
\hline 2 2. & $\begin{array}{l}\text { Stacy (orangtua) : "Kurasa bukan } \\
\text { hak ku mengatakan apapun. } \\
\text { Kurasa masalah ini biasanya } \\
\text { dimulai dalam rumah tangga." }\end{array}$ & $\begin{array}{ll}\text { MEDIUM } & \text { CLOSE } \\
\text { UP } & \text { layar } \\
\text { komputer } & \end{array}$ \\
\hline Time : 00:57:28 - 00:58:00 & \multicolumn{2}{|l|}{ Set: :- } \\
\hline
\end{tabular}

1. Denotasi

Signifier: Visualisasi dan dialog scene 13

Signified: Masyarakat bebas mengutarakan pendapatnya di internet terutama pada media sosial.

Pada gambar pertama menampilkan seorang perempuan bernama Stacy yang diwawancarai terhadap tanggapannya tentang kasus hilangnya Margot. Menurutnya masalah tersebut ditimbulkan dalam rumah tangga. 
2. Konotasi

Setelah berita tentang hilangnya Margot ramai dan banyak diperbincangkan orang. Muncullah berbagai spekulasi atau pendapat orang-orang. Hingga mulai mengarah tentang \#ParentFail atau kegagalan orangtua. Ada yang beranggapan bahwa penyebab hilangnya Margot adalah ayahnya. David pun menjadi korban cyber bullying. Terdapat unggahan foto David yang di edit dengan tulisan sarkas "Father of the year" dan juga banyak bermunculan tulisan masyarakat yang menyudutkan David. Masyarakat berpikir bahwa sikap David sebagai seorang ayah sudah gagal. David dituduh telah memperlakukan Margot dengan tidak baik sehingga membuatnya kabur dari rumah.

3. Mitos

Media sosial seolah menjadi buku harian setiap individu. Semua orang bebas menulis apa saja termasuk mengutarakan pendapatnya. Masyarakat jadi bebas berspekulasi tanpa mempertimbangkan perasaan orang lain. Tak jarang kata-kata yang tertulis di media sosial bisa menyakiti orang lain dan termasuk dalam tindakan bullying atau perundungan.

\section{e. Kecanduan internet}

Kecanduan internet (internet addiction disorder) adalah ketidakmampuan individu dalam mengontrol penggunaan internet sehingga mengakibatkan terjadinya masalah psikologis, sosial, dan pekerjaan pada kehidupan individu tersebut (Young \& Rogers, 1998:25). Dikutip dari laman resmi We are social (Kemp, 2020), pada Januari 2020 tercatat sebanyak 175,4 juta masyarakat di Indonesia merupakan pengguna aktif internet. Internet addiction dapat mengakibatkan berkurangnya interaksi sosial, bahaya radiasi, menjadi introvert, sehingga menurunnya kemampuan penglihatan. 
Memperlihatkan adegan David mencari daftar laman web yang paling sering dikunjungi Margot yaitu website Youcast (aplikasi live blogging). David secara acak mengklik apa saja yang ada di laman tersebut karena ia tidak mengerti tentang Youcast hingga akhirnya menemukan tentang saved cast (video live yang disimpan) di akun Margot. Ternyata Margot lebih nyaman dan terbuka ketika berkomunikasi dengan teman dunia mayanya yang memiliki username fish_n_chips.

Tabel 5 Scene 11 film "Searching"

\begin{tabular}{|l|l|l|}
\hline VISUAL & DIALOG / NARASI & TYPE OF SHOT \\
\hline Margot: "Kau bekerja 25 jam demi & $\begin{array}{l}\text { CLOSE UP layar } \\
\text { komputer } \\
\text { bisa sekolah?" } \\
\text { Fish_n_chips : "Hanya sampai } \\
\text { ibuku keluar dari rumah sakit. } \\
\text { Kanker sialan." } \\
\text { (Cast selanjutnya): } \\
\text { Fish_n_chips : } \\
\text { menyuruhku berhenti sekolah hari } \\
\text { ini. Tagihan Rumah Sakit. Dia } \\
\text { bahkan tidak memintanya. Ku } \\
\text { harap aku bisa dekat dengan } \\
\text { ayahku, sepertimu" } \\
\text { Margot : "Ayahku tak tahu aku } \\
\text { berhenti les piano" } \\
\text { Fishn_chips : "M engapa kau tak } \\
\text { katakan padanya." } \\
\text { Margot: "Dia tak akan paham" }\end{array}$ \\
\hline Time : 00:39:55 - 00:45:45 & \begin{tabular}{l} 
Set : Kamar Margot \\
\hline
\end{tabular} \\
\hline
\end{tabular}

1. Denotasi

Signifier: Visualisasi dan dialog scene 11

Signified: Masyarakat maya memiliki lebih banyak teman di dunia maya daripada kehidupan sehari-hari

Pada gambar pertama terlihat David sedang membuka akun Youcast M argot. la memutar semua saved cast M argot. Terlihat M argot lebih sering 
curhat dan mengutarakan emosinya di akun Youcast nya. la juga sering berkomunikasi dengan akun fish_n_chips seperti yang terlihat pada gambar kedua.

2. Konotasi

David memutar semua saved cast Margot. Ia menyadari bahwa Margot lebih senang mengutarakan perasaannya di akun Youcast nya. la mempunyai teman di dunia maya tetapi tidak di dunia nyata. Hal tersebut terjadi semenjak Margot kehilangan ibunya. Di Youcast Margot sering berkomunikasi dengan akun fish_n_chips yang mengaku bernama Hannah. Margot merasa dekat dengan Hannah karena latar belakang mereka yang cukup mirip yaitu tentang ibu Hannah yang dirawat di Rumah Sakit akibat penyakit kanker.

3. Mitos

Penggunaan internet terutama dalam mengakses media sosial dapat memunculkan sifat ketagihan (addiction). Seseorang yang tidak memiliki rasa kenyamanan dalam kehidupan sehari-harinya biasanya melampiaskan dengan aktif di dunia maya. Pada media sosial siapa saja bisa mengekspresikan perasaannya. Ketika memiliki rasa kenyamanan, seseorang cenderung mau terbuka mengenai perasaannya hingga hal-hal pribadinya. Sedangkan pada dunia nyata, biasanya saat mengekspresikan perasaan manusia takut untuk mendapatkan tanggapan atau respon langsung dari oranglain. 


\section{Hasil Analisis Representasi :}

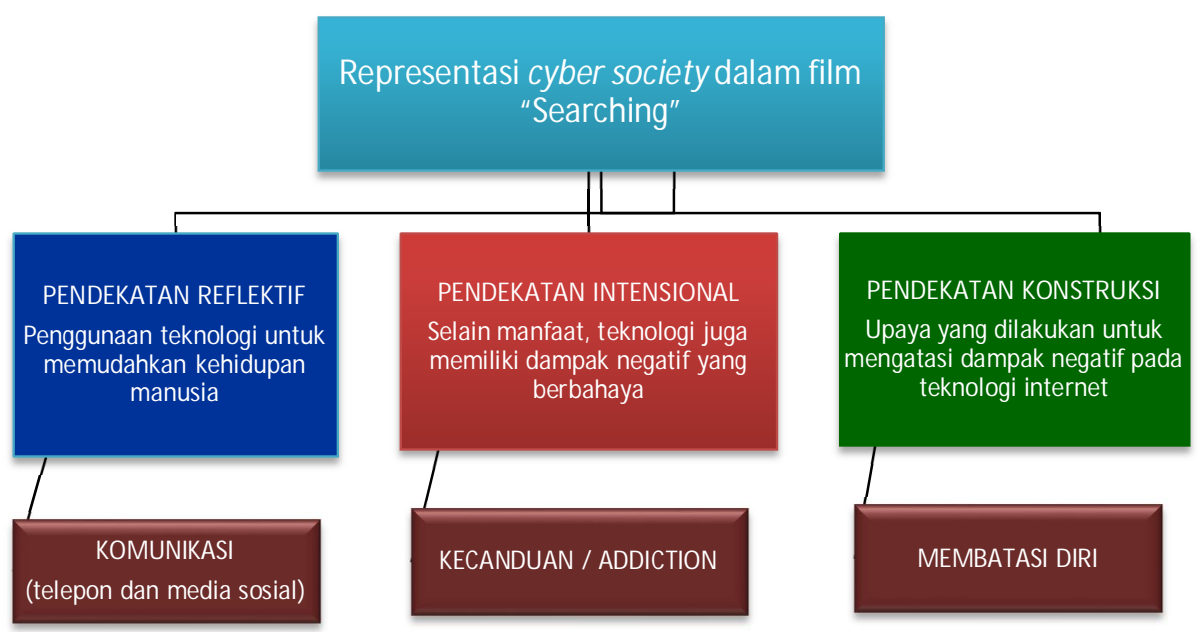

Gambar 2. Representasi cyber society dalam film "Searching"

\section{Pendekatan reflektif (reflectif approach)}

Pada film "Searching" penggunaan teknologi internet memiliki andil besar dalam membantu pencarian salah satu tokoh yang hilang. Diperoleh pemaknaan tentang masyarakat cyber yang bergantung dengan teknologi dalam kehidupan sehari-hari seperti yang digambarkan pada film "Searching" terutama dalam hal kemudahan komunikasi.

2. Pendekatan intensional (intentional approach)

Dalam film "Searching", selain memperlihatkan tentang berbagai manfaat yang dimiliki teknologi dibidang internet untuk memudahkan manusia disepanjang alur film, sutradara juga menyelipkan pesan di akhir film. Sutradara memberikan plot twist berupa penyalahgunaan teknologi internet sebagai alasan dibalik hilangnya salah satu tokoh.

\section{Pendekatan konstruksi (constructionist approach)}

Film "Searching" telah memaparkan manfaat dan dampak negatif teknologi internet yang dapat membahayakan manusia. Hal tersebut membuat penonton menyadari bahwa teknologi internet bagai pisau bermata dua, namun kehidupan manusia tidak bisa dipisahkan dari teknologi. Film 
"Searching" diharapkan menimbulkan kesadaran agar bijak dalam menggunakan teknologi internet.

\section{Simpulan}

Berdasarkan penelitian yang dilakukan penulis pada representasi cyber society dalam film "Searching" dengan menggunakan analisis semiotika Roland Barthes. Makna denotasi yang ditemukan pada scene dalam film tersebut adalah pemaparan mengenai adegan-adegan yang menggambarkan bahwa aktifitas sehari-hari masyarakat cyber sangat berdampingan dengan teknologi informasi dan komunikasi terutama dalam bidang internet. Digambarkan masyarakat cyber menggunakan media perangkat sebagai hardware dan website/aplikasi sebagai software. Makna konotasi menjelaskan bahwa teknologi internet merupakan media massa yang bebas diakses oleh setiap orang, sehingga dapat pula disalahgunakan bahkan memicu hal-hal negatif. Dalam film dijelaskan pula dampak negatif yang dimiliki internet seperti cyber bullying, cyber crime, dan penyebaran berita bohong (hoax).

Makna mitos yang terkandung dalam film "Searching" adalah bahwa internet dapat di ibaratkan sebagai pisau bermata dua. Teknologi internet dipercaya memiliki jutaan manfaat yang dapat memudahkan kehidupan manusia baik dari faktor pendidikan, sosial, dan ekonomi. Masyarakat cyber tidak boleh dibutakan dengan bahaya yang dimiliki internet. Terdapat lima poin yang dihasilkan dari analisis representasi cyber society dalam film "Searching" yaitu: (1) Komunikasi menggunakan media aplikasi, (2) Menciptakan identitas baru di dunia maya, (3) Menggunakan website untuk mencari informasi, (4) Kebebasan berpendapat di dunia maya, dan (5) Kecanduan internet. Penelitian ini

dimaksudkan agar masyarakat dapat meningkatkan kesadaran (awareness) terhadap dampak-dampak yang dimiliki teknologi terutama dalam bidang internet sehingga dapat hidup bijak di era digital. 


\section{Daftar Pustaka}

Abdullah, Dimas Lazuardy. (2018). Analisis Semiotika M akna Islam dalam Film Pengabdi Setan. Skripsi. Universitas Islam Syarif Hidayatullah Jakarta.

Bungin, Burhan. (2007). Sosiologi Komunikasi. Jakarta : Kencana Perdana Media.

Chornelia, Yolanda Hana. (2013). Representasi Feminisme Dalam Film Snow White And The Huntsman. Jurnal E-Komunikasi, 1(3).

Deegan, Marilyn dan Simon. (2002). Digital Futures : Strategies for the Information Age. London: Library Association Publishing.

Effendy, Onong Uchjana. (2003). IImu, Teori, Filsafat komunikasi. Bandung: Citra Aditya Bakti.

Hall, Stuart. (2002). Representation: Cultural representations and signifying practices. London: Sage Publications.

IM Db. (2018). Searching. Dalam https://www.imdb.com/title/tt7668870/ (diakses pada 20 Februari 2020 pukul 20.00 WIB).

Kemp, Simon. (2020). Digital 2020 : 3.8 Billion People use Social Media. Dalam https://wearesocial.com/blog/2020/01/digital-2020-3-8-billion-peopleuse-social-media (diakses pada 15 M ei 2020 pukul 19.30 WIB).

McLuhan, Marshal. (2003). Understanding Media : The Extension of Man. London \& New York : Gingko Press.

M cQuail, Denis. (2003). Teori komunikasi M assa Suatu Pengantar. Edisi Kedua. Jakarta: Erlangga.

Nasrullah, Rulli. (2016). Media Sosial: Perspektif Komunikasi, Budaya, dan Sosioteknologi. Bandung : Simbiosa Rekatama M edia.

Nugraha, Rahmadya Putra. (2014). Pengaruh New Media terhadap Perkembangan Cyber society. Prosiding Seminar Besar Nasional Komunikasi. Padang, 26-27 November $2013: 683$.

Pedersen, Erik. (2018). 'Search' Wins Alfred P. Sloan Foundation Film Prize Sundance. Dalam https://deadline.com/2018/01/sundance-alfred-psloan-foundation-film-prize-search-1202267711/ (diakses pada 18 Januari 2020 pukul 14.00 WIB).

Surahman, Sigit. (2014). Representasi Perempuan M etropolitan dalam Film 7 Hati 7 Cinta 7 Wanita. Jurnal Komunikasi. 3 (1) : 39-63.

Sobur, Alex. (2009). Semiotika Komunikasi. Remaja Rosda Karya : Bandung. Strauss, Judy dan Frost. (2012). E-M arketing edisi Internasional ke 6. London : Pearson. 
Jurnal Audience: Jurnal Ilmu Komunikasi

Vol 03 No. 02 Tahun 2020

Wibowo, Indiawan Seto. (2013). Semiotika Komunikasi : Aplikasi Praktis Bagi Penelitian dan Skripsi Komunikasi. Jakarta: M itra Wacana M edia.

Widiarini, Anissa Dea. (2020). Berkat Digitalisasi, Semua Aktivitas Kini Berada di Genggaman.

Dalam https://lifestyle. kompas.com/read/2020/03/10/100200020/berkatdigitalisasi-semua-aktivitas-kini-berada-di-genggaman. (diakses pada 21 Agustus 2020 pukul 19.00 WIB). 